UDC 533.9

\title{
The Principle of Creating Quasiperiodic Surfaces under the Action of a Vibrating Dielectric Matrix
}

\author{
M. O. Zozyuk ${ }^{\mathrm{f}}$, ORCID $\underline{0000-0001-9116-7217}$ \\ A. I. Yurikov, ORCID 0000-0001-8620-9902 \\ D. V. Koroliouk ${ }^{\mathrm{s}}$, Dr.Sc.(Phys.-Math.) Senior Research, ORCID 0000-0003-2765-3450 \\ Yu. I. Yakymenkos, Dr.Sc.(Eng.) Prof., ORCID 0000-0002-8129-8616 \\ National Technical University of Ukraine "Igor Sikorsky Kyiv Polytechnic Institute" \\ Kyiv, Ukraine
}

\begin{abstract}
A method for creating metasurfaces using a standing wave, formed in a dielectric, is proposed. Such metasurfaces are formed from metal suspensions, are deposited on a dielectric plate, is placed in a metal frame-screen. A method of creating standing waves is presented. The Chladni`s principle is used for creating acoustic figures was taken as the basis. Mathematical description of this model is proposed, as well as the main research methods.
\end{abstract}

Keywords — standing wave; metasurfaces; Chladni figures; discrete diffusion model.

\section{INTRODUCTION}

Recently, many methods have been demonstrated for creating meta-surfaces for different purposes: for fullspectrum perfect solar energy absorption [1], for controlling shear vertical waves [2], for multiband superabsorption and terahertz sensing [3]. This paper presents a method for creating metasurfaces that will solve many actual problems in the future.

The use of standing waves in plates to create surface structures has long been demonstrated by Ernst Chladni. In that case, the acoustic standing waves form in plate, onto which elastic material is then applied or strewed. It will repeat the arrangement of nodes and antinodes of the standing wave on plate. This work aims to describe the methods of material selection for creating electromagnetic standing waves when appear surface reliefs similar to Chladni figures (Fig. 1) using the electromagnetic (not acoustic) excitation. [4]
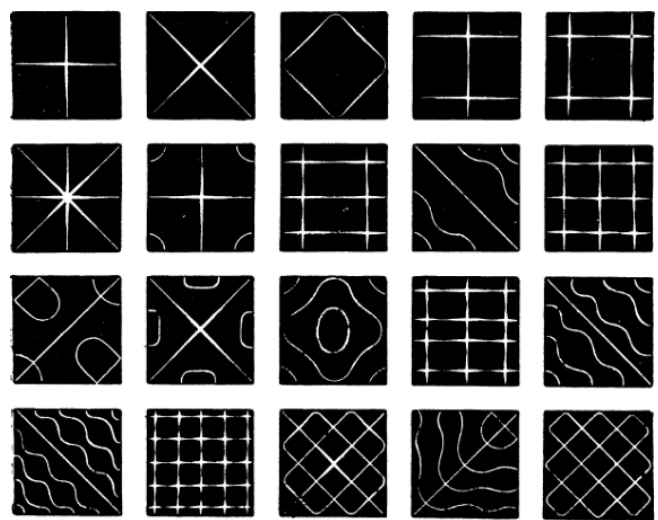

Fig. 1 Chladni figures at different frequencies
Note that the propagation of electromagnetic waves in a dielectric, causes different polarization mechanisms. For each dielectric, the polarization frequency will be different.

An important task is the optimal choice of relief-forming material that will be applied to dielectric. A number of factors must be taken into account, such as electron plasma susceptibility, wettability, melting point, isomorphism, and others.

Our goal is to develop practical recommendations on the selection of materials with different properties, as well as methods for their study, in order to create metasurfaces using the method of vibrating dielectric matrix. In this case, the factors of physical model should be taken into account, such as diffusion processes under amorphous state of materials, isomorphism of materials, thickness of layers of materials, methods of applying materials at different scales, ensuring the degree of purity of medium, the creating conditions that will make possible to study the surface structure ("drawings") and so on.

\section{DIELECTRIC MEDIUM AND THE EXCITATION ACTION}

The problem of optimal choice of dielectric should be solved on the frequency of standing wave. And this, in turn, substantially determines the morphology of the obtained metasurfaces. The basic formula for calculating the dielectric matrix is

$$
\varepsilon=1+\frac{N \alpha}{1-N \alpha \beta},
$$

where $N$ is the number of electrons in all atoms per unit volume of the substance, $\alpha$ - polarizability, $\beta$ - constant, for most dielectrics $1 / 3$. Polarizability $\alpha$ is defined as 
the ratio of the dipole moment of atoms to the value of field strength and has a volume dimension [5].

Formula (1) allows us to calculate the dielectric constant that depends on the field frequency, as well as the loss tangent:

$$
\tan (\delta)=\frac{\left|\varepsilon^{\prime \prime}\right|}{\varepsilon^{\prime}}=\frac{\sigma}{\omega \varepsilon_{0} \varepsilon^{\prime}},
$$

where $\omega$ - electromagnetic field frequency, $\varepsilon "$ is the imaginary component of the dielectric constant, $\varepsilon^{\prime}$ is the real component, $\sigma$ is the conductivity [7].

Of course, the losses can be compensated by the field strength, but this does not mean that the dielectric will contain a standing wave with the necessary functional characteristics, since it is necessary that the field strength is sufficient to move the material along the surface of the dielectric.

Figure 2 illustrates typical behavior of the real and imaginary parts of dielectric constant in a wide frequency range [7]

The regions of sharp changes in these components correspond to absorption lines, which can have different nature: dipole or ion relaxation, atomic and electron resonances at high frequencies [8].

As an example, there are materials based on multiwalled carbon nanotubes with various diameters and morphologies [9]. To study nanotubes, a polyethylene matrix is used, in which nanotubes are embedded. In [10], the real and imaginary components of permeability were shown in the range of $2-4$ at frequencies from 0.2 to $2.8 \mathrm{THz}$.

There is also a great potential for liquids and gases in which the dielectric constant is sufficient (1-1.5) in certain condition. For example, the Argon in liquid state $(\mathrm{T}<83.8 \mathrm{~K})$, have electric permeability about 1.5 , while with increasing temperature the permeability will drop down to one.

Of interest is also possible use of dielectric matrices in semiconductors. In silicon crystals, electron polarization is present due to the existence of valence electrons. In [11], the results of studies of electron and ion polarization of various silicate-containing materials are presented, which gives promising possibilities for experimental study of dielectric matrices.

The behavior of the joint characteristics (parameters) of the materials is essential. To study them, the dependences of permeability on the frequency, temperature, layer thickness, number of defects, and purity will be investigated. It is assumed the covariance functions of equilibrium (stationary) random processes are used to statistically identify the dependence of some parameters on others.

First of all, we are interested in electron and ion polarization depending on frequency and temperature. Next, dielectric losses, which may be associated with an increase of temperature and frequency, should be studied. In addition, it is necessary to study the compatibility of dielectric material with important experimental parameters, such as alloying, wettability, and others.

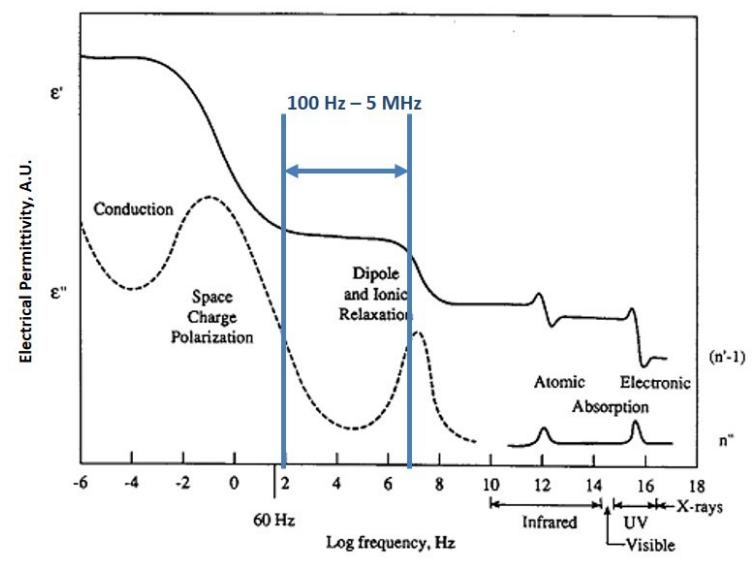

Fig. 2 The dielectric constant components

\section{SURFACE LAYER MATERIAL SELECTION}

The selected material that should be susceptible to external electromagnetic field and at the same time smoothly and easily moving along the surface and repeats the shape of a standing wave (nodes and antinodes). Here, such parameters as the volume of electron plasma (the number of free electrons), the melting point, and the magnetic and electric susceptibility are important. Depending on which component of the wave will be used to move the material, the selection of the appropriate surface material will be implemented.

For the electrical component of standing wave, a material with a high electrical susceptibility must be used so that the shielding length is sufficient to capture as many electrons in the surface layer as possible, ideally to capture the entire volume of the material.

The material should be selected according to the following parameters: screening length, as well as "skin layer", melting temperature, degree of wettability, fusion, temperature and frequency dependence of the constituent components.

So, if the electrical component is used, then the shielding length should be calculated, as follow:

$$
l_{e}=\sqrt{\varepsilon \varepsilon_{0} k T / e^{2} n_{0}},
$$

where $n_{0}$ is concentration of electrons in the initial state, $T$ is temperature, $k$ is Boltzmann constant.

Formula (8) determines the depth of penetration of the electric field into dielectric matrix.

Nodes and antinodes form a force field architecture that controls the charges inside the surface layer and ultimately ensures the reordering, together with the charge, of the material.

To describe this process, it is proposed to use the wellknown formulas [12] for the amplitudes of electric and magnetic components at the surface:

$$
\begin{gathered}
E_{m}(z)=E_{1 m}^{+}\left|1+\dot{\rho} e^{i 2 k_{1} z}\right|, \\
H_{m}(z)=E_{1 m}^{+}\left|1-\dot{\rho} e^{i 2 k_{1} z}\right| / Z_{r},
\end{gathered}
$$

where $k_{l}$ is the wave number, $z$ is the coordinate in space, $E_{l m}$ is the amplitude of the electric component at the origin, $\dot{\rho}$ is the reflection coefficient, $Z_{r}$ is the wave resistance of the environment. 
Using these formulas, the behavior of waves in a dielectric environment is simulated and the location of a standing wave (its nodes and antinodes) in a dielectric can be illustrated ("drawn").

As promising materials there are alloys based on magnesium $(\mathrm{Mg})$, gallium $(\mathrm{Ga})$, cadmium $(\mathrm{Cd})$, tin $(\mathrm{Sn})$, bismuth (Bi) and others [12]. It is important to keep in mind alloys based on metals at the top of electrochemical series of activity and having a low melting point [13]. The most suitable metals are magnesium, aluminum, zinc, but difference from metals with strong chemical activity, such as sodium, potassium and other alkali metals.

By analogy with the calculation of the material for electrical component, calculation of material for the magnetic component is the following: determination of the screening length of magnetic field, magnetic susceptibility of the metal, degree of wettability, fusion, temperature and frequency dependence of the components of material. There are materials based on ferromagnetic fluid inside some neutral environment such as polyacrylic acid, soya lecithin, water, sodium polyacrylate, glycerol and others.

There is a number of other materials can be useful due to their low melting point and at the same time magnetic properties: paramagnets - cesium, aluminum, magnesium and others (more active), mixtures of ferromagnets and ferrites, as well as alloys based on them.

In [14], it was demonstrated that with increasing the temperature, the magnetic susceptibility increases, and the same materials have a low melting point.

The metals can be mixed with liquid substances to achieve special electromagnetic properties: metal powder mixed with glycerin, isoparaffins, transformer oil, metals with a low melting point (gallium, tin, bismuth, indium, as well as their alloys [15]).

It is important to consider other parameters, for example, fusion temperature of materials, as well as via wettability. The calculation of the components becomes more complicated as various experimental factors grow.

A study is planned on of the permeability dependence by variation of temperature, material purity, number of defects, layer thickness and other electrophysical parameters. A statistical analysis of the dependence of the experimental configuration of the chosen parameters will be also investigated.

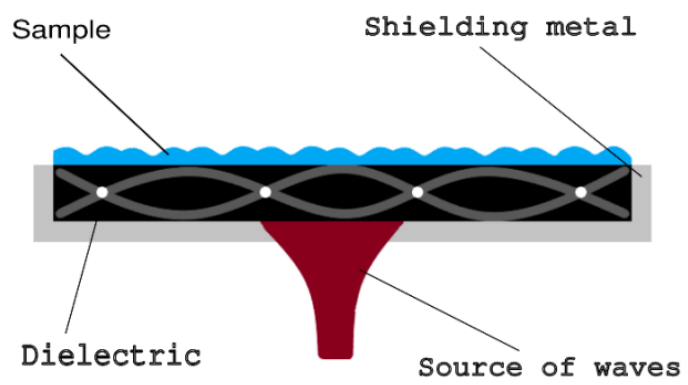

A large amount of researches consider boundary conditions for the study of model. Such restrictions permit to focus the model parameters in the domain of interest.

\section{THE DYNAMICS OF THE CONSTITUENT MECHANISMS OF THE EXPERIMENT}

Depending on the frequency, on component of standing wave, the layer thickness will be determined. The main criterion is that the entire volume of surface layer is used by the field, and therefore, that the effective movement of the material is realized.

Depending on the field frequency, on layer thickness, roughly speaking, on the scaling of the experiment, methods for applying the layers will be different. It is necessary to provide a number of preparatory steps, such as cutting a dielectric to create boundary conditions for a waveguide-dielectric, applying a transition layer at the interface between dielectric and surface layer, in order to avoid fusion of boundary materials, which cannot be allowed in any way (Fig. 3). Therefore, the configuration of dielectric matrix substantially depends on the parameters of the physical model.

To take into account the priority of parameters, it is necessary to determine which processes are more valuable for the successful conduct of experiment, and which in the end may not affect morphology of surface relief at all.

Firstly, it is necessary to consider in this context, these are the processes that accompany the experiment in the active stage. In any case, diffusion processes will be involved, since the operating temperatures can be higher than the boundary temperature, and accordingly, the effects of melting will grow disproportionately fast.

The above setups are associated with the former state of a standing wave and a fixed morphology of the metasurface. A change in the characteristics of the dielectric matrix, as well as the parameters of emitted electromagnetic wave, implies a redistribution of surface masses and a significant change in the morphology of surface of the metasern. It is important to understand the practical significance of such "smooth regulation". The dynamics of changes in the morphology of the metasurface is described as a stationary diffusion process, which is a solution to the difference stochastic equation:

$$
\Delta \alpha_{t+1}=-V \alpha_{t}+\sigma \Delta W_{t+1}, t \geq 0,
$$

where $0<V<1 ; \quad \alpha_{t}, t \geq 0$ is the "proportional" thickness of the metal layer at a fixed point of the dielectric matrix, $\Delta W_{t+1}, t \geq 0$, is the standard Wiener process (Brownian motion) with mathematical expectation 0 and standard deviation 1.

The drift and diffusion parameters $V$, $\sigma$ characterize the dynamics of the process $\alpha_{t}, t \geq 0$ [16]. An important property of the diffusion model (7) is the conditions of the statistical equilibrium of the system expressed in terms of the regression functions [17], which makes it possible to constructively pose the problem of establishing relations between the parameters $V, \sigma$ and the parameters $\varepsilon, \mu, \lambda$, as well as with other characteristics of

Fig. 3 Schematic installation 
the physical model for creating metasurfaces using a standing wave.

The dynamic diffusion model also makes it possible to numerically emulate [18] the solutions of the difference stochastic equation (8) with given parameters for a preliminary analysis of the dynamics of the metal layer thickness with a change in the basic parameters of the physical model.

A more complex approach to studying the dynamics of changes in the surface morphology of the metasurface with changing parameters of the physical model $\varepsilon, \mu, \lambda$ and some matrix configuration parameters can be mathematically modeled as a dynamic diffusion model (9), generalized to the case of discrete diffusion in a random or deterministic medium [19]. That is, the coefficients of the difference stochastic equation depend on the parameters of the external environment $x(t)$ and can be represented:

$$
\Delta \alpha_{\delta}(t)=-\delta^{2} V(x(t)) \alpha_{\delta}(t)+\delta \sigma \Delta W(t),
$$

where the scaled increment is defined as $\Delta \alpha_{\delta}(t):=\alpha_{\delta}\left(t+\delta^{2}\right)-\alpha_{\delta}(t), \quad \delta$ is a small scaling parameter, $\delta \rightarrow 0$.

Another model for changing the surface morphology of the metasurface is the consideration of discrete diffusion in a balanced medium [19], which corresponds to a stable state. That is, the leading parameter is $V(x)$, $x \in E$, which can take both positive and negative values, provided that the random environment is balanced:

$$
\int_{E} \rho(d x) V(x)=0,
$$

where $\rho(d x)$ is the invariant measure of the external influence.

Then the difference stochastic equation has the form

$$
\Delta \alpha(t)=-\hat{V} \alpha(t)+\hat{\sigma} \Delta W(t)
$$

where the coefficients of the equation are the following:

$$
\begin{aligned}
\widehat{V_{0}} & =\widehat{V_{0}^{2}}-\widehat{V^{2}}, \widehat{\sigma_{0}^{2}}=\widehat{\sigma^{2}}+\left(2 \widehat{V_{0}^{2}}-\widehat{V^{2}}\right) s^{2}, \\
\widehat{V_{0}^{2}} & :=\int_{E} \rho(d x) V(x) \mathbb{R}_{0} V(x), \widehat{V^{2}}:=\int_{E} \rho(d x) V^{2}(x), \\
\widehat{\sigma^{2}} & :=\int_{E} \rho(d x) \sigma^{2}(x) .
\end{aligned}
$$

where the operator $\mathbb{R}_{0}$ is the generalized inverse operator of $\mathbb{Q}=\mathbb{P}-\mathbb{I}$, that is $\mathbb{Q} \mathbb{R}_{0}=\mathbb{R}_{0} \mathbb{Q}=\Pi-\mathbb{I}$, where $\mathbb{P}$ is the transient state operator of the external influence, II is the identity operator and $\Pi$ is the projector onto the subspace of zeros of the operator $\mathbb{Q}$, defined by the equality

$$
\Pi \varphi(x)=\int_{E} \rho(d x) \varphi(x) .
$$

To take into account transient processes and relaxation, one can also use the equation with asymptotically infinitesimal diffusion [17], namely

$$
\Delta \alpha_{\delta}(t)=-\delta^{3} V(x(t)) \alpha_{\delta}(t)+\sqrt{\delta} \sigma \Delta W(t),
$$

where the scaled increment is defined as $\Delta \alpha_{\delta}(t):=\alpha_{\delta}\left(t+\delta^{3}\right)-\alpha_{\delta}(t), \quad \delta$ is a small scaling parameter, $\delta \rightarrow 0$.

\section{CONCLUSION}

The basic components of an experiment to create quasiperiodic matrices based on a vibrating dielectric plate are considered.

Directions for research and selection of materials for their use in the experiment are indicated. When finding the optimal dielectric, one must pay attention to the polarization components, since different polarization mechanisms take place at different frequencies.

In the context of the selection of materials, a preliminary study of all components on the compatibility and suitability of their use in the design ranges of parameters is also necessary.

Also, mathematical methods are proposed for studying diffusion processes to understand the consequences of isomorphism of materials, and they will also make it possible to study the dynamics of material movements on surface of a plate.

The described method, by assumption, will have to be used to create resonators, filters, and also converters of a new type (based on artificial configurations and materials) for frequency ranges that are carefully studied at the present time. Created structures will be carefully researched for their use as indicated elements.

\section{REFERENCES}

[1] M. I. Hossaina, N. Yumnam, W. Qarony, A. Salleo, V. Wagner, D. Knipp, Y.H. Tsang, "Non-resonant metal-oxide metasurfaces for efficient perovskite solar cells", Solar Energy, vol. 198, pp. 570-577, March 2020 , DOI: $10.1016 /$ j.solener.2020.01.082.

[2] Z. Liu, H. Zhong, H. Zhang, Z. Huang, G. Liu, X. Liu, G. Fu, C. Tang, "Silicon multi-resonant metasurface for full-spectrum perfect solar energy absorption," Solar Energy, vol. 199, pp. 360-365, March 2020,

DOI: $\underline{10.1016 / \mathrm{j} . \text { solener.2020.02.053. }}$.

[3] M. S. Islam, J. Sultana, M. Biabanifard, Z. Vafapour, M. J. Nine, A. Dinovitser, C. M. B. Cordeiro, B. W.-H. Ng, D. Abbott, "Tunable localized surface plasmon graphene metasurface for multiband superabsorption and terahertz sensing," Carbon, vol. 158, pp. 559-567, March 2020, DOI: $10.1016 /$ j.carbon.2019.11.026.

[4] M. Faraday, "On a Peculiar Class of Acoustical Figures; and on Certain Forms Assumed by Groups of Particles upon Vibrating Elastic Surfaces," Philosophical Transactions of the Royal Society of London, vol. 121, pp. 299-340, 1831, DOI: $10.1098 / \mathrm{rspl} 1830.0024$.

[5] M. Houssa, "High-k Gate Dielectrics", CRC Press, 601 p., 2004, https://www.routledge.com/High-k-Gate-Dielectrics/Houssa/p/book/9780367454449.

[6] A. M. Prokhorov, "Fiziceskij encyklopediceskij slovar", Ed. Sovetskaya Encyclopedia, 1983, http://www.libex.ru/detail/book138229.html.

[7] L. D. Landau, E. M. Lifshitz, "Course of Theoretical Physics. Electrodynamics of Continuous Media. 2nd edition," Butterworth-Heinemann, vol. 8, pp. 460, 1979, https://www.sciencedirect.com/book/9780080302751/electrodynamics-ofcontinuous-media. 
[8] P. C. Clemmow, "An introduction to electromagnetic theory," University Press. pp. 183., 1973, https://www.cambridge.org/ua/academic/subjects/physics/general-and-classical-physics/introduction-electromagnetic theory?for$\underline{\text { mat }=\text { PB\&isbn }=9780521098151}$.

[9] V. L Kuznetsov, I. A. Simonova, A. I. Stadnichenko, A.V. Ishchenko, "Oxidation behavior of multiwall carbon nanotubes with different diameters and morphology", Appl. Surf. Sci., vol. 12, pp. 258-298, 2012, DOI: 10.1016/j.apsusc.2012.03.021.

[10] Tae-In Jeon, Joo-Hiuk Son, Kay Hyeok An, Young Hee Lee and Young Seak Lee, Terahertz absorption and dispersion of fluorine-doped single-walled carbon nanotube. Journal of Applied Physics - v. 10.- p. 3-4, 1998, DOI: $10.1063 / 1.2001751$.

[11] A.C. Lasaga, R.T. Cygan, "Electronic and ionic polarizabilities of silicate minerals," American Mineralogist, vol. 67, pp. 328-334, 1982, https://www.sandia.gov/geo/Pubs/Lasaga1982AM.pdf.

[12] D.R. Lide CRC Handbook of Chemistry and Physics (87th ed.). Boca Raton, FL: CRC Press. 2006, https://academia.edu/33987940/Handbook of Chemistry and Physics 84th David R Lide.

[13] Y.V. Tolstobrov, N.A Manakov, M.V. Pletneva, "The phenomenon of thermal magnetization of highly anisotropic single crystals," Tech. Phys. Lett., vol. 32, pp. 332 - 327, April 2006, DOI: $10.1134 /$ S106378500604016X.

\section{Надійшла до редакції 14 травня 2020 року}

[14] M.V. Strikha, A.I. Kurchak, A.N. Morozovska, "Influence of Domain Structure in Ferroelectric Substrate on Graphene Conductance," (Authors' Review), Ukr. J. Phys, vol.63, pp. 4969, 2018, DOI: $10.15407 /$ ujpe63.01.0049.

[15] D. Koroliouk, "Stationary statistical experiments and the optimal estimator for a predictable component," Journal of Mathematical Sciences, vol. 214(2), pp. 220-228, 2016, https://www.dspace.nbuv.gov.ua/handle/123456789/140874.

[16] D. Koroliouk, V.S. Koroliuk, and N. Rosato, "Equilibrium Processes in Biomedical Data Analysis: The Wright-Fisher Model", Cybernetics and Systems Analysis, vol. 50, n. 6, 890897, 2014, DOI: $10.1007 / \mathrm{s} 10559-014-9680-\mathrm{y}$

[17] D. Koroliouk, "Statistical experiments in a balanced Markov random environment," Cybernetics and Systems Analysis, vol. 51, pp. 766-771, 2015, DOI: 10.1007/s10559-015-9769-

[18] D. Koroliouk, "The problem of discrete Markov diffusion leaving an interval", Cybernetics and Systems Analysis, vol. 52, n. 4, 571-576. 2016, DOI: $10.1007 / \mathrm{s} 10559-016-9859-$ $\underline{5}$.

[19] D. Koroliouk, "Two component binary statistical experiment with persistent linear regression," Theory of Probability and Mathematical Statistics, vol. 90, pp. 103-114, 2015 , DOI: $10.1090 /$ tpms/952. 
УдК 533.9

\section{Принцип створення квазіперіодичних поверхонь під дією вібраційної діелектричної матриці}

Зозюк ${ }^{\mathrm{f}}$ M. O., ORCID 0000-0001-9116-7217

Юріков A., ORCID 0000-0001-8620-9902

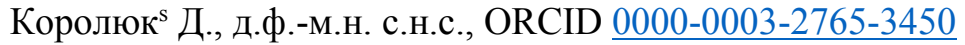

Якименко ${ }^{\mathrm{S}}$ Ю. І., д.т.н. проф., ORCID 0000-0002-8129-8616

Національний технічний університет України

"Київський політехнічний інститут імені Ігоря Сікорського"

Київ, Україна

Анотація-Запропоновано метод створення метаповерхностей за допомогою стоячої хвилі, сформованої в діелектрику. Такі метаповерхні формуються 3 металевих суспензій, наносяться на діелектричну пластину, поміщаються в металевий каркас-екран. Представлений метод створення стоячих хвиль. За основу був використаний принцип Хладні для створення акустичних фігур. Запропоновано математичний опис цієї моделі, а також основні методи дослідження.

Залежно від частоти, та складової стоячої хвилі визначасться товщина шару. Основним критерісм с те, що весь об'см поверхневого шару використовується полем, а отже, і забезпечується ефективний рух матеріалу.

Залежно від частоти поля, від товщини шару, грубо кажучи, від масштабування експерименту, методи нанесення шарів будуть різними. Необхідно передбачити ряд підготовчих етапів, таких як різання діелектрика для створення граничних умов для хвилеводу-діелектрика, нанесення перехідного шару на межі між діелектриком та поверхневим шаром, щоб уникнути сплавлення межових матеріалів, що не можна дозволяти будь-яким способом. Тому конфігурація діелектричної матриці істотно залежить від параметрів фізичної моделі.

Щоб врахувати пріоритетність параметрів, необхідно визначити, які процеси с більш цінними для успішного проведення експерименту, а які, зрештою, можуть взагалі не вплинути на морфологію рельєфу поверхні.

По-перше, слід враховувати в цьому контексті, процеси, які супроводжують експеримент на активній стадії. У будь-якому випадку будуть задіяні дифузійні процеси, оскільки робочі температури можуть бути вище граничної температури, і відповідно ефекти плавлення зростатимуть непропорційно швидко.

Вищеописані установки пов'язані з колишнім станом стоячої хвилі та фіксованою морфологісю метаповерхні. Зміна характеристик діелектричної матриці, а також параметрів випромінюваної електромагнітної хвилі передбачає перерозподіл поверхневих мас та значну зміну морфології поверхні.

Ключові слова - стояча хвиля; метаповерхні; фігури Хладні; дискретна модель дифузії. 